\title{
The Love of David and Jonathan: Ideology, Text, Reception, by James E. Harding
}

BibleWorld | Acumen, 20 I 2 | 450 pages | ISBN: 978-I-84553-6756 (hardcover) $£ 75.00$

Much has been written on the bond of David and Jonathan in the past decade, including substantial chunks of three comparative monographs, two of them

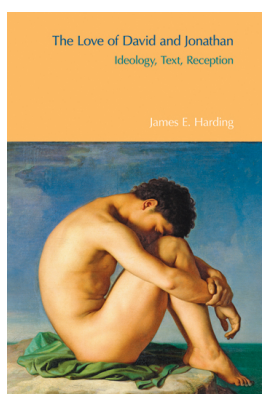
penned by this reviewer. It was thus to be expected that book-length explorations of this possibly homoerotic pairing would appear sooner rather than later. Amazingly, specialists have barely digested the first of these (Anthony Heacock, Jonathan Loved David: Manly Love in the Hebrew Bible and the Hermeneutics of Sex [Sheffield, $20 \mathrm{II}$ ]), than a second one, longer and far more technical, comes out. The originality of the work of Harding is that it does not attempt to offer yet another interpretive grid. Instead of smoothing out the edges of a highly recalcitrant text either to maintain the conservative stance or to champion an homoerotic reading, The Love of David and Jonathan, while embracing and firmly inclining towards a progressive line ("I am convinced that taking the homophobic sting out of scripture and its interpretation is something to which energy should be devoted.... I am offering instead what I think is a necessary, corrective footnote to a troubled debate," $\mathrm{x}$ ), sets out to explore what is so fascinating and problematic in this relationship. Why are equally competent scholars deadlocked to such an extent on the nature of the bond between David and Jonathan? How did the passages of the book of Samuel where they interact become an ideological battlefield for laymen and academics alike, whereas what we can call the issue of the concealed homosexuality of the heroes does not seem to exist for ancient readers, Jewish and Christians, of the Hebrew Bible? As the work 
looks overwhelming, forbidding even, and we will find reasons to suspect that the author wanted it that way, this must be a searching review, one in which I shall attempt not to dwell too much on the points where I see myself more or less directly challenged.

The first chapter of the book ("Battling for David and Jonathan: Scripture, Historical Criticism, and the Gay Agenda," 5 I-I 2 I) offers, in Harding's own words, "a kind of metacommentary" that "seeks to determine how and why scholars disagree on the nature of the relationship between David and Jonathan, what agendas determine their approaches and conclusions, and what assumptions they bring to the texts" (3I). The picture drawn is convincing, occasionally lurid, and succeeds in conveying a sense of the ideological battle royale the scholarly discourse over this bond has degenerated into. It equally unravels in adequate terms the tight linkage between the reception the passages of interest for David and Jonathan have enjoyed since the nineteenth century, mostly in English-speaking countries, and the questions anglophone exegetes ask of them: now more than ever, I Samuel operates as a magnifying glass for faith-based, societal concerns in the United States. (Parochial concerns could hardly be avoided here.) However, since Harding has decided that another objective Forschungsbericht was less necessary than a narrative of the ideological grounds on which the latest interpreters have dealt with the texts, he fails to bring any objective criteria to his account of these landmark studies; which weakens his exposition of the impasse reached by studies on David and Jonathan. The most impassioned research receives the lion's share of attention: Markus Zehnder's 2007 paper gets twenty pages, seven each are devoted to the landmark article by Silvia Schroer and Thomas Staubli and the relevant chapter in Robert Gagnon's The Bible and Homosexual Practice, and eleven lump together the various queer readings. On the other hand, neither the few pages devoted to David and Jonathan in the epoch-making Homoeroticism in the Biblical World: A Historical Perspective (Minneapolis, I998) by Martti Nissinen nor the elaborate I999 study by the same scholar appear out of the notes, whereas both Susan Ackerman and myself receive less than half a page each at the outset of the chapter, under the artificial heading "Exegetical fractional strife," as if our contributions somehow stood outside the mainstream Harding will subsequently map out. Obviously, the clearly progressive stance she and I advocated was of more concern to him than the actual finer points of our approach to the texts. This is disappointing, to say the least, but hardly surprising since this chapter does not jump straight on the bandwagon. Indeed it comes after a lengthy 
introduction ( $\mathrm{I}-5 \mathrm{O})$ in which Harding guides us through a roster of recent, English-speaking movies and TV programs which engage one way or the other with the affection between David and Jonathan (I-I 5 ) before he unravels the way preoccupations with the resonance for LBGTQ folks of this bond have increasingly come to dominate the scholarly exegesis of the second half of I Samuel down to our times (I 5-3 I). It was only to be expected, from a man of faith zeroing in on the theory of reception, that the Assyriologist Nissinen, the historian of the Hebrew religion Ackerman, and the Classical and Near Eastern philologist Nardelli would be negatively singled out, for in the entire scale of the David-Jonathan literature, our scholarly methods are the most sharply discrepant from those of the Evangelical mainstream, whether "liberal" or conservative, to which Harding belongs. The three of us were not congenial to Harding's theoretical survey; whether this evinces an amount of prejudice I leave to others to decide. On the other hand what stands beyond doubt is that any assessment of the status quaestionis of David and Jonathan from the viewpoint of the ideology adhered to which fails to recognize the importance of no less than three substantial contributions can hardly claim the higher ground; particularly if, as will be seen presently, this assessment passes over yet more vital items.

Apart from such issues of omission and commission, there is nothing in the introduction and chapter one that one has to take issue with; nothing one imperiously needs to know before one embarks on a study of the texts, too, and here lies the trouble. These longish preliminaries testify to the author's awkward stance (Harding is both academic and ordained clergyman but loath to be viewed as an ivory-tower type in the pursuit of purely antiquarian ventures) more than they cast light on the modern relevance of the tales about David and Jonathan or the raison d'être of his project. This is not to say that nothing can be learned from chapter one, quite the contrary; for instance, the methodological flaws of Zehnder's and Gagnon's constructs are nicely worked out $(63-83,83-89)$. Yet Harding gives more than once the impression of either beating a dead horse or reinventing the wheel, sometimes at the cost of the representativeness and scholarly credibility of his sample. Precious few interpreters of the relationship between David and Jonathan not aligned with the Religious Right take Gagnon seriously nowadays, so it was unnecessary to devote a fair deal of attention to his, purely negative, preaching; there was little need to rehearse at length the vastly overstated thesis of Schroer and Staubli (57-63); the overview of the queer readings (David Jobling, Roland Boer, Theodore Jennings, Yaron Peleg, Anthony Heacock) is tightly packed 
but has the misfortune of missing one critical contribution, by Tod Linafelt (infra); I also lament the absence of a few lines on the conservative yet not stridently homophobic approach of Richard M. Davidson, Flame of Yahweh: Sexuality in the Old Testament (Peabody, 2007), 165-67, since this weighty tome has already proven influential and is unapologetic on the principles of his handling of the Bible (he entitles his chapter 3, I 33-76, "Human Heterosexuality versus Homosexuality, Transvestism, and Bestiality”); last but not least, so few were the ripples made in print by Zehnder's transparently malignant piece of theology that a rebuttal of his strategy did not count among the discipline's most pressing needs, unless it also laid bare the half-truths, distortions, and instances of utter ignorance with which the "Observations on the Relationship Between David and Jonathan and the Debate on Homosexuality" bristles. Unfortunately, Harding got cold feet and stops short of providing this demonstration (my Aristarchus antibarbarus: Pseudologies mésopotamiennes, bibliques, classiques [Amsterdam, 201 2], xxxiv-xxxvi, I $36-$ 53 , attempts to satisfy this need). As one may legitimately quibble at some of Harding's decisions with respect to what belongs in the main text and what was better relegated to the notes—apart from Nissinen, Jonathan Rowe, "Is Jonathan Really David's 'Wife'? A Response to Yaron Peleg," Journal for the Study of the Old Testament 34 (2009): 183-93, too does not get the honours of the text, probably because Harding is contemptuous of its arguments, cf. I 2 In2 I 6 top: "a rather wooden approach to reading both the biblical text and Peleg's rather subtle argument," the conclusion that Harding's materials got the better of him because of an unorthodox angle of attack and some personal quirks seems hard to resist.

The second part of the work, a (semiotic) commentary on the sections of the books of Samuel which have been supposed to evidence a same-sex affair between our protagonists (chapter two, "How Open is the David and Jonathan Narrative?" I22-273) to which are prefixed outstanding methodological prolegomena, will be widely read and quoted by virtue of its qualities as a competent doxography. I cannot praise enough the section which shows, against Zehnder and Gagnon, the irrelevance and sheer danger of bringing to bear on David and Jonathan the Leviticus verses on homosexuality (I4556). "What is necessary ... is to examine the David and Jonathan narratives with a view to the degree to which it is more or less open, or more or less closed," Harding tells us (I34). And indeed his overview achieves much and possesses solid virtues. The author strongly points out that too many incertitudes at the narratological, linguistic, and formulaic-referential levels lurk 
behind either maddeningly obscure phrases and sentences or deceptively simple lexemes for the consistent application of a committed type of reading to be more than wishful thinking; so much so that Harding ends up marshalling twelve particular instances in which the meaning of the Hebrew is unlikely ever to be retrieved $(225-27)$. To his greatest credit, it will be much harder now to maintain that the narrative is so consistent and lucid in its theological preoccupation with the political rise of David that either homosociability or homoeroticism would be out of place there (Gagnon, Zehnder, and most recently Jonathan Rowe, Sons or Lovers: An Interpretation of David and Jonathan's Friendship [New York, 20I 2], I29n8); to seriously consider that the first encounter between David and Jonathan, with their initial covenant (I Sam I 8:I-4), does not represent an extraordinary situation in the entire Hebrew Bible for which no parallel is forthcoming and no ready-made solution exists; or to refuse to entertain the possibility that the whole gamut of the interactions of the two characters is riddled with linguistic ambiguities that may perfectly have been intended as such by the narrators, qua a code. Harding's "How Open is the David and Jonathan Narrative?" will also put renewed pressure on the shoulders of scholars striving for definitive, anthropological guidance in the texts. Rowe only reaches firm conclusions in his new monograph because he shuts his eyes to the openness mapped out by Harding:

the moral good that guides the narrative's plot is the one of life itself: will David live? What will happen to Jonathan's sons? The goods of filial obedience and family loyalty are important because they are both assumed and used by all three men. Also prominent are the goods of friendship and covenant loyalty. Yet further goods in the David-Jonathan narratives, each with a moral dimension, include personal and family honour, hereditary succession, truthfulness and trustworthiness. Among this multiplicity of moral goods and the inevitable conflicts between them, moves God, a fact of which readers are frequently reminded by the characters' appeal to him.... We turn, then, to the second question raised in the Introduction, viz. how the conflict of moral values is resolved by each character. Importantly, all the characters in the David-Jonathan narratives do something: faced with a moral conundrum they decide upon a particular course of action. These choices comprise the "resolu- 
tion" of the value clashes in the selected biblical texts and vary according to how each of the protagonists perceives the moral goods in play. (1 30 ; original emphases)

The story asserts that when the validity of societal norms conflicts with loyalty to David's house they should be rejected. Just as Jonathan in preferring David stood against not only Saul but also the dominant moral schema of family loyalty and filial obedience, so readers should recall that loyalty to YHWH's anointed—and his successors—is paramount. (I 32)

Let us hope that such generalizations will become scarce now that we have at the ready Harding's robust parsing of the passages of interest for David and Jonathan. I ought finally not to count among the achievements of his chapter its demonstration that scarcely anyone engaging with these texts escapes apologetic concerns and interests, even though there will be readers to deem this one of Harding's major results; for impassive, ideology-free scholarship is but a dream, particularly in the human sciences. However, the ideological blinkers through which Rowe thought himself justified to tailor the book of Samuel to make it fit his preconceived notions about the family, warriortype society, and divine election in Early Israel shows how much this was an essential point to make - the texts are never more pellucid than for those whose interests lie in keeping things simple. Those readers will suffer now that they have to contend with Harding's central chapter to The Love of David and Jonathan.

These virtues unfortunately come with serious drawbacks. I cannot tell whether Harding wanted to produce a basic compendium for Bible scholars, theologians, and historians of sexuality seeking to understand the limits within which any interpretation of the enigmatic relationship between the two biblical heroes must fight its way; for chapter two does not attempt a compilation of all there is to know about David and Jonathan. Instead, Harding frames the debate in postmodern terms whose fuzziness drowns out whatever sophistication they can claim, and goes his merry way with a magisterial disregard for the original views of his predecessors whenever these ideas could not be construed within, or accomodated into, the semiotic framework he sticks to. This adherence to formal criticism is best seen in Harding's extreme concern with narratological issues, à la Jan P. Fokkelman: he carries this, no doubt respectable, trend in biblical studies to the point that he fails to engage with the textual stratigraphy of the heavily redacted book 
of Samuel once he has paid lip-service to it (134-37, cf. 226). Thus we are to understand that there seems to exist little difference, in his eyes, between the commentary of Robert P. Gordon and the French one of André Caquot and Phillippe de Robert. Furthermore, I find it difficult to avoid the conclusion that Harding exhibits the mindset of a clergyman when he refuses to consider an erection in the abrupt ending of I Sam 20:4 I (2 I 5) and writes a note in which he snaps at classicists inclined to multiply homosex$\mathrm{ual} /$ pederastic obscenities in the wake of Dover on what might be overstated or unstable grounds (267-68n464; too bad for Harding, the one historian of Greek sexuality he endorses here is James Davidson, viz. an author whose malevolence towards Kenneth Dover shortcuts through the evidence, and all-round bad scholarship dramatically diminishes his authority: see Thomas K. Hubbard's review in Humanities and Social Sciences Online (2009), and Aristarchus antibarbarus, 56-80). Although very knowledgable in Hebrew, Harding equally tends to favor solutions which shy away from textual criticism. Let one case-in-point suffice: faced with the end of I Sam 20:4I, he equivocates, does not discuss my suggestion, rooted in the Septuagint, that we have here a sexual climax-he tersely mentioned it in another context (I I4nI32)_and falls back on the wholly ad hoc supposition of an ellipsis adumbrated by David T. Tsumura, all because this device leaves the Hebrew exegetically open-ended.

The somewhat narrow range of his reading further weakens his commentary. He has not consulted, say, Athalya Brenner, The Intercourse of Knowledge: On Gendering Desire and "Sexuality" in the Hebrew Bible (Leiden and New York, I997); Jacques Vermeylen, La loi du plus fort: Histoire de la rédaction des récits davidiques de I Samuel 8 à I Rois 2 (Leuven, 2000), which actually is a commentary; or Barbara Green's short but acute King Saul's Asking (Collegeville, 2003). On the dirge preserving David's last and most poignant expression of his affection for Jonathan, Harding has remained unaware of the all-important Tod Linafelt, "Private Poetry and Public Eloquence in 2 Sam I : I7-27: Hearing and Overhearing David's Lament for Jonathan and Saul," The Journal of Religion 88 (2008): 497-526, who insists on the erotic overtones of I:26b (522-25); he has missed too Nissim Amzallag and Michal Avriel, "Complex Antiphony in David's Lament and Its Literary Significance," Vetus Testamentum 60 (2010): I-I4, which is valuable both for the thematic composition of the piece and for the significance of the verse dedicated to Jonathan (cf. 9: "in the couple $20 / 26$ of verses, the love of Jonathan becomes antithetic to the happiness of the Philistine women. Moreover, a 
composite meaning emerges, and it totally differs from the linear meaning [related to the so-called homosexuality of David and Jonathan]. Now, it becomes the joy of the philistine women that surpasses the 'jubilation' they may feel from love, as soon as they will hear about the death of Jonathan," not without note I6: "the sexual connotation is even strengthened by the use, in verse 20, of the terms ta 'aloznah [they jubilate] and 'arelim [uncircumcised] in relation to these women"). It would serve no purpose to marshal further instances where Harding did not keep abreast of the scholarly literature, resulting in a somewhat stunted exposition. Even his bibliographical engagement with biblical and Rabbinic homosexuality is not quite all that it should be: one looks in vain at least for two seminal titles by Michael S. Satlow (“They Abused Him Like a Woman': Homoeroticism, Gender Blurring, and the Rabbis in Late Antiquity," Journal of the History of Sexuality 5 [1994]: I-25; Tasting the Dish. Rabbinic Rhetorics of Sexuality [Atlanta, 1995], 198-222) and for Dale Launderville, Celibacy in the Ancient World: Its Ideal and Practice in Pre-Hellenistic Israel, Mesopotamia, and Greece (Collegeville, 2010), 174-76, who accepts "that there was a sexual dimension to the friendship" of David and Jonathan (I74), whereas the importance of an article by Saul M. Olyan ("Surpassing the Love of Women' : Another Look at 2 Samuel I: 26 and the Relationship of David and Jonathan', in Mark D. Jordan (ed.), Authorizing Marriage? Canon, Tradition, and Critique in the Blessing of Same-Sex Unions [Princeton-Oxford, 2006], 7-16) has not been perceived outside of the petty polemics of Zehnder against it. No-one shall be surprised, then, that ancient Near Eastern comparanda were kept out of the scene unless they appeared in Harding's favored sources, even after I had identified precise links between Levantine institutions and the three successive covenants Jonathan engages David into. Since Harding failed to provide an account on what, in my mind, is the major intriguing feature of the second half of I Samuel, viz. the two sets of relationships between David, Saul, and Jonathan, and David, Jonathan, and Michal; and as his commentary of the seminal verse of David's elegy (2 Sam I:26), at pages 216-20, operates in isolation by not considering the composition of this sophisticated poem and by narrowing the interpretive range of the verse far beyond what seems advisable, I feel bound to conclude that his overview of the primary texts ( $60-227,243-73)$ is both too full on numerous well-known facts and seriously deficient or inadequate in cases of real difficulty. It will not do to plead, as per pages I60-6I, that the author purposely refrained from dealing with, and quoting, the secondary literature in anything like a comprehensive 
manner. As one who has published four books, let me be blunt and patronizing: a scholar, especially a junior one working at his first monograph, who is unafraid of filling forty pages in small print of endnotes to some of his chapters, ought not to exhibit such reluctance at all; it is bound to look coy, if not outright insincere. All the more so when said scholar repeatedly indulges himself in writing annotations that amount to three quarters of a page (70 on 44-45; 5 on IOI-2; I9 on 23 I-32; 240 on 252 ; 250 on 253 ; 498 on $270-7 \mathrm{I}$; 69 on $372-73$; I 2 I on $378-79$; I 30 on $380-8$ I 2 IO on $386-87 ; 262$ on $39 \mathrm{I}-92$ ) and stretches notes beyond what is tolerable even at a remove from the main text. Just consider $37-38$ s.v. 40 , on the "old and rather tired" essentialist versus social constructionist divide: either such a bibliographical dissertation could be tailored to the body of the relevant chapter or it had to be drastically curtailed. Encyclopedic learning is good and dandy when you really have left out nothing important; otherwise, unkind readers may suspect you of throwing smoke screens. We just sampled how much Harding can be faulted on this count.

More successful seems to me his third, and last, chapter, on the Rezeptionsgeschichte of the two friends through the ages ("David and Jonathan between Athens and Jerusalem," 274-402, substantially revising the article published in Relegere I (201 I): 37-92). It demonstrates how their bond was redefined in the nineteenth century in the context of the self-affirmation of homosexual(-leaning) artists, to whom the Greek ideas about pederasty and the Greek traditions of same-sex pairings provided a ready-made analogy. The two Hebrews integrated the mainstream of gay literature as an iconic ideal, on the same footing as Achilles and Patroclus but with much more clout than them: "it becomes harder to separate David and Jonathan from the genealogy of homosexuality as such, because their friendship was an integral part of the tradition of male love that contributed to the emergence of the very notion of homosexuality whose applicability to the David and Jonathan narrative has become the subject of dispute" (365). Harding's wide-ranging and, so far as I can tell, accurate survey shall be praised to the high heavens; not that it contributes much to the bond between the Biblical heroes though, for I strongly disagree with the conclusion he draws on page 365 : "... the subject of dispute. To ask whether the relationship between David and Jonathan was 'homosexual,' then, is to mistake the effect for the cause. A much more meaningful question concerns the role David and Jonathan played in the emergence of the modern idea of homosexuality itself." One must look askance at the analogy drawn with the Homeric pairing. Whatever 
the fame of the bond of David and Jonathan, what I take to be its latent homoeroticism did not help much, contrary to Harding's own words (33), "to shape a very modern sense of an ancient heritage of love between men," inasmuch as David and Jonathan never buoyed the Judeo-Christian expressions of male-male affect the way the bond between Achilles and Patrocles did for the ancient Greeks themselves. First of all, The Love of David and Jonathan remains mum on the earliest witness to the narrative of these heroes, in chapter 62 of the Liber Antiquitatum Biblicarum; for this enigmatic pseudepigraph tones down things so much that their relationship looks trite and conventional there, if still warmly personal (in the lack of other studies, read my Le motif de la paire d'amis hérö̈que à prolongements homophiles: Perspectives odysséennes et proche-orientales [Amsterdam, 2004], 65-66, 69-70, 78). So is it standard scholarly protocol, in terms of intellectual history, to equate a male twosome whose sexual dimension was openly considered from Antiquity onwards, with another one that never evinced such a questioning until the Romantic period? Second, Harding's section on Achilles and Patrocles, 29I-98, is reduced to grasping at straws to obtain the close parallel with David and Jonathan he needs instead of the topical discrepancy I champion. On a theme broached in many excellent, or at least well-informed, accounts (from the little known Peter Mauritsch, Sexualität im frühen Griechenland: Untersuchungen zu Norm und Abweichen in den homerischen Epen [Vienna etc, 1992], I I 5-20, to Marco Fantuzzi, Achilles in Love: Intertextual Studies [Oxford, 2012], I 87-235), Harding could do no better than work out a crudely superficial sketch which unfavorably compares even with the most eccentric account by a Classicist (André Sauge's denial that Achilles feels very deeply for Patroclus: Iliade: Langue, récit, écriture [Bern etc, 2007], I 3 I-39). These pages smack of an ill-advised interloper in Greek studies, to the extent that the relevant secondary sources, no matter how readily available, have been ignored. How can one claim to deploy with minimal competence, e.g., Aeschines' speech Against Timarchus, its attack on shameful, Attic homosexuality, and its use of the exemplum of Achilles and Patroclus, detached from Nick Fisher's richly commentated translation (Oxford, 200I), notably at pages 286-93, and from any of the studies of the argumentative tactics of this barrister (they are listed in Aristarchus Antibarbarus, 6on Io)? Who but a partisan amateur can get it into his mind to explain how Aeschines appeals both to the Homeric heroes and the pederastic pair Harmodios and Aristogiton (292-93), link the latter to the episodes of Thucydides and the Athenaiôn politeia attributed to Aristotle in which they star (37I-72n62), 
then use none of the standard treatments of these twin sources? To mention but one resource, Simon Hornblower, A Commentary on Thucydides, III (Oxford-New York, 2008), has much to say on Harmodios and Aristogiton, at 434-40. Finally, unlike the Graeco-Roman chapter in John Boswell's much-maligned Same-Sex Unions in Premodern Europe, this section of Harding focusses far too little on linguistic issues, not even when the specifics of the affection of Achilles and Patroclus directly depend on them, such as the phraseology used in Against Timarchus, $\$ \$$ I 42 sqq., or in the Aeschylean fragment on Patroclus's thighs. So Aeschines, $\S_{1} 42$, toys with his audience and the readers of his written oration by claiming that Homer $\tau \dot{\partial} \nu \mu \dot{\varepsilon} \nu$ " $p \omega \tau \alpha \kappa \alpha \grave{\imath}$ $\tau \dot{\eta} \nu \dot{\varepsilon} \pi \omega \nu \nu \mu i \alpha \nu \alpha \dot{\nu} \tau \tilde{\omega} \nu \tau \tilde{\eta} s \phi i \lambda i \alpha \varsigma \dot{\alpha} \pi \circ \kappa p \dot{\pi} \pi \tau \varepsilon \tau \alpha l$, "hides away the desire and the fact of naming their friendship," quite an unnatural expression (hendiadys?) to convey his sense of Homer's dissimulation of what was really at stake, by avoiding those words who would cast on a true light what Achilles and $\mathrm{Pa}$ troclus were for each other. Neither Fisher, who translates "keeps their erotic love hidden and the proper name of their friendship" (I 04), nor Harding, who leaves out much of the force of $\dot{\varepsilon} \pi \omega \nu \nu \mu i \alpha$ ("derived or significant name" $L S J$ ) when he renders "keeps hidden their love and the name of their friendship," do pause to comment on the studied affectation of style and syntax

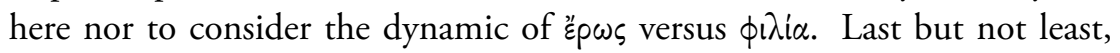
to make matters worse, the view of Greek male-male love and sex conspicuous in the notes to these pages of Harding, nay elsewhere in his monograph, rests on a fairly superficial grasp of the facts: Harding deems ancient homosexuality something to be ascertained from a comparison between the works of Dover or Halperin and Davidson's The Greeks and Greek Love, with assistance from Cantarella and Crompton on the side - quite a long fall from the heights of Ackerman's understanding. In this respect, the one interpreter Harding most resembles is Zehnder, even though he steps short of reverting, like the latter, to the essentialist viewpoint. To sum up: the reception of the stories about David and Jonathan is superbly narrated in the last chapter of the work under review; its main thesis on the cardinal part played by this tradition on the emergence of modern gay identities looks cogent; but the linkage between the Hebrew pairing and the bond of Achilles and Patrocles established by nineteenth and early twentieth-centuries advocates of homosexuality according to Harding amounts to an exaggeration reached on the basis of a misstated analogy.

This checkered view of the character of the book takes further ammunition from the poor workmanship of the indices and scholarly apparatus, 
si parva licet componere magnis. Endnotes appear after each chapter (34-50; IO0-I 2 I; 228-73; 366-402; 405-6), but neither an index verborum nor an index rerum have been provided to help the user navigate these, unusually difficult to locate, clusters of bibliographical lore, marginal comment, and secondary pleading. This makes for a much harder read than it should have been. Though the responsibility for the scattered endnotes might well lay, ultimately, with the publisher rather than with the author, it complicates a great deal the task of the reader. Academics will persist, lay persons are likely to get frustrated and either skip the annotation or discard the monograph (all the more so since they are only offered an index of modern names and another of quotes). A further issue can confidently be put at the author's door: the most technical parts of the chapter devoted to the mapping of the primary evidence pro and cons an homoerotic affair behind the dealings of David and Jonathan have been printed in a smaller type "so that readers can, if necessary, skip dense sections that might lead to missing the forest for the trees" (I73). It is easy to see that this serves a severely limited purpose. Indeed Harding only translates whole Hebrew verses and snippets making connected sense, not, or not enough, single words. What is stranger still, he never ever transliterates anything Semitic, not even his occasional Syriac snippets: are the Masoretic text or the Peshitta supposed to count for easy, not "dense," matters? On the other hand, non-Biblical Greek always comes equipped with a translation extending to one-word quotes, as if such an evidence somehow were more out-of-the-way than the Biblia Hebraica Stuttgartensia. This spectacular double standard not only deepens the dryness of the most technical parts of chapter two, to which the small print was supposed to draw attention; the lack of help with the Hebrew compared with the assistance with the Greek signposts a desire to cater to readers who can parse the Semitic languages but are at sea when faced with Classical Greek. Obviously, broadening the audience of the book was little more than idle talk, and the coyness of the author already showcased by the size of the endnotes compared to his emphatic refusal to be comprehensive in matters bibliographical, peers here too. Why I spoke of a deliberately forbidding book at the outset of this disquisition is now crystal-clear: monumentality has been meant to triumph over modesty. Omne ignotum pro magnifico? Not quite.

In conclusion, Harding wrote an evaluation of the impasse in which the philologically elusive relationship of David and Jonathan has pushed scholars that succeeds in recognizing what is "open" in the primary texts from what is not, or rather, from what provides food for conservative apologetics 
and Bible-based politics. He also builds a strong case for considering this bond as vital in the literary debates out of which the definition of modern homosexuality was born. The net result is a box of tools that will stimulate "liberal" interpreters, who seldom oversimplify the Hebrew nowadays, into sharpening their reading grids, while complicating the labor of staunch traditionalists and homophobic theologians. Historians of the reception of the Bible, as well as laypersons interested in the past of queer and gender studies, should benefit too. Neither Harding's admirable culture though, nor his industry, obvious commitment, and sound biblical training make the 450page Love of David and Jonathan. Ideology, Text, Reception an innovative inquiry casting shadows on the most thoroughly competent treatment to date of the nature of this pairing, viz. Susan Ackerman, When Heroes Love: The Ambiguities of Eros in the Stories of Gilgamesh and David (New York, 2005), I65-23 I, cf. 285-99 for the endnotes. That Harding did not intend to replace her discussion of David and Jonathan in no way signifies that he had to remain systematically indecisive as to the nature of their bond peering through in specific Hebrew phrases, or favor semiotic interpretations apt to sound disingenuous in that they fail to address what she had to say. Harding easily snatches from Heacock the honor of being the best evangelical attempt at a compromise between "liberal" or queer interpretations and conservative skepticism, he provides a trustworthy first aid to the major passages under debate in the book of Samuel keyed in to the most mainstream exegetical options, but other than that, his work falls flat and delivers relatively little on both the texts and the ideology of their interpreters, while having significant weaknesses of its own. To have taken more exegetic risks, notably on the ancient Near Eastern and Classical Greek sides, and applied stronger judgement on what to include and what to leave out, would probably have made it more profitable. 